\title{
PERCUTANEOUS TRANSHEPATIC BILIARY DRAINAGE - THE FIRST STEP IN THE TREATMENT OF MALIGNANT BILIARY OBSTRUCTION
}

\author{
Romualdas Riauka, Povilas Ignatavičius, Giedrius Barauskas \\ Lithuanian University of Health Sciences, Department of Surgery
}

Key words: biliary obstruction, percutaneous, transhepatic, drainage.

\begin{abstract}
Summary
Introduction. Percutaneous transhepatic biliary drainage (PTBD) comes as safe and effective alternative when endoscopic biliary decompression is unavailable. However, PTBD as invasive procedure has its own risks and complications. Our aim was to evaluate the clinical outcomes and possible benefits of an ultrasound guided percutaneous transhepatic biliary drainage as the first step in the palliative treatment of malignant biliary obstruction.

Methods. Retrospective review of patients undergoing percutaneous transhepatic biliary drainage from January 2014 to December 2015 at the Department of Surgery, Hospital of the Lithuanian University of Health Sciences was performed. Patients were reviewed for demographic data, laboratory tests, complications, outcomes, hospital stay and mortality rate.

Results. During the study period ninety nine patients (median age - 68 years, (44 - 95) received 124 biliary drainage procedures for malignant obstructive jaundice. Prior the percutaneous drainage fifty eight patients $(58.6 \%)$ were unsuccessfully treated by ERCP. Forty patients $(40.4 \%)$ were diagnosed with periampullary tumours, thirty $(30.3 \%)$ had proximal/hilar cholangiocarcinoma, and twenty nine (29.3\%) had biliary obstruction due to metastatic disease. Acute cholangitis was present in fifty two $(52.5 \%)$ patients. After drainage procedure total serum bilirubin decreased in eighty seven $(87.9 \%)$ patients (from $293.72 \pm 131.9 \mu \mathrm{mol}$ to $193.11 \pm 117.49 \mu \mathrm{mol}$, $\mathrm{p}<0.05)$. Reduction in Gammaglutamyl transferase and Alkaline phosphatase was observed in ninety four $(94.9 \%)$ patients. Seventy patients $(70.7 \%)$ underwent additional interval procedures. In $62(88.6 \%)$ cases
\end{abstract}

percutaneous transhepatic biliary stenting was performed. The mean hospital stay was $25.5 \pm 17.9$ days (after percutaneous drainage - 19.9 \pm 17.3 days). Thirty four (34.3\%) patients developed drainage related morbidity, with drainage catheter dislocation being most common $(76.5 \%(\mathrm{n}=26)$. In hospital mortality rate was $27.3 \%(n=27)$ with one drainage related death (procedure related mortality rate $-3.7 \%$ ).

Conclusions. Percutaneous transhepatic biliary drainage is relatively safe and effective method to reduce malignant obstructive jaundice, when other, less invasive drainage methods are unavailable or ineffective and acts as a necessary step in further palliative treatment.

\section{Introduction}

Malignant biliary obstruction is a serious complication of hepatobiliary tract malignancies and occurs when bile ducts are obstructed either by direct tumour infiltration or external compression [1]. Bile flow to duodenum is blocked and patients usually presents with jaundice, fever and cholangitis. General patient condition is impeded and further administration of chemotherapy is restricted [2]. Most common malignancies associated with obstructive jaundice are hilar cholangiocarcinoma, periampullary tumours (tumours of pancreatic head, duodenum, distal common bile duct or papilla of Vater) and metastases to porta hepatis from malignancies of various localizations [3]. At the time of diagnosis most of these tumours are unresectable, carrying poor prognosis, and making palliative treatment the only option. In order to prevent cholangitis, sepsis and other jaundicerelated complications biliary drainage should be performed, with endoscopic drainage being the first choice option [4]. Percutaneous transhepatic biliary drainage (PTBD) comes as safe and effective alternative when endoscopic biliary decompression is unavailable due to proximal biliary obstruction, altered anatomy associated with previous surgery 
or poor general patient condition [4]. However, PTBD as invasive procedure has its own risks and complications.

The aim of this study was to evaluate the clinical outcomes and possible benefits of an ultrasound guided percutaneous transhepatic biliary drainage as the first step in further treatment of malignant biliary obstruction.

\section{Materials and Methods}

A retrospective single center study was performed at the Department of Surgery, Lithuanian University of Health Sciences patients, who were managed at our Department from 01-01-2014 to 31-12-2015 were included. Data was collected using specially developed and prospectively maintained database.

During the two year period one hundred twenty three patients underwent successful PTBD procedures. We excluded twenty four patients with benign or unverified biliary obstruction. Ninety nine patients met the inclusion criteria: (1) diagnosed primary/metastatic hepatobiliary tract malignancy; (2) elevated serum bilirubin and/or jaundice symptoms; (3) unsuccessful previous endoscopic drainage procedures; (4) successful PTBD. Diagnosis was made by radiological evaluation (abdominal ultrasound, computed tomography, magnetic resonance tomography imaging) and/or histological verification (ultrasound guided biopsy, intraoperative findings).

Patients were reviewed for demographics, laboratory tests prior to $\mathrm{PTBD}$, complications related to percutaneous drainage, outcomes (laboratory tests at the time of discharge and/or additional interval

Table 1. Causes of malignant biliary obstruction.

\begin{tabular}{|l|c|}
\hline Diagnosis & n (\%) \\
\hline Periampullary tumours & $40(40.4 \%)$ \\
\hline Pancreatic head & $31(31.3 \%)$ \\
\hline Papilla of Vater & $6(6.1 \%)$ \\
\hline Distal common bile duct & $2(2 \%)$ \\
\hline Duodenum & $1(1 \%)$ \\
\hline Hilar cholangiocarcinoma & $30(30.3 \%)$ \\
\hline Liver metastases & $29(29.3 \%)$ \\
\hline Colon and rectum & $11(11.1 \%)$ \\
\hline Gynaecological and breast & $4(4 \%)$ \\
\hline Stomach & $4(4 \%)$ \\
\hline Pancreas & $4(4 \%)$ \\
\hline Gallbladder & $3(3.1 \%)$ \\
\hline Unknown location & $3(3.1 \%)$ \\
\hline
\end{tabular}

procedures), hospital stay and mortality rate. The Kaunas Regional Biomedical Research Ethics Committee approved the study (protocol no. BEC-MF-177) and allowed the use of publicly unavailable database.

Drainage procedure. Depending on the location of the bile duct obstruction, a right intercostal and/or left epigastric approach was chosen. The appropriate intrahepatic bile duct was punctured under ultrasound guidance using 21 Gauge $(G)$ needle. A 0.035 " guidewire was introduced into the bile duct. After the tract dilatation, a $6 \mathrm{Fr}$ drainage catheter was passed over the guidewire, followed by cholangiography.

Statistical analysis. Statistical analysis was performed using SPSS 20.0 for Windows (SPSS Inc., Chicago, USA). The data are presented as mean \pm Standard deviation or median and range. For comparison between groups, the Mann-Whitney test or Student's $t$ test was employed where appropriate. $\mathrm{P}<0.05$ was considered statistically significant.

\section{Results}

We have analyzed data from 99 patients (F:M ratio 1.3) who have been admitted to Surgical Department over a two year period because of malignant biliary obstruction. Median age of patients was 68 years, ranging from 44 to 95 years. Forty patients (40.4\%) had obstructive jaundice because of periampullary tumours. In thirty patients (30.3\%)

Table 2. Improvement of biochemical markers.

GGT - Gamma-glutamyltransferase; ALP - Alkaline phosphatase; AST-Aspartate transaminase; ALT - Alanine transaminase

\begin{tabular}{|l|c|c|c|c|}
\hline Marker & Prior drainage & $\begin{array}{c}\text { After drai- } \\
\text { nage }\end{array}$ & P & $\begin{array}{c}\text { Patients } \\
\text { with decrea- } \\
\text { sed values, } \\
\text { n (\%) }\end{array}$ \\
\hline $\begin{array}{l}\text { Total serum } \\
\text { bilirubin( } \mu \mathrm{mol} / \mathrm{L})\end{array}$ & $293.72 \pm 131.9$ & $193.11 \pm 117.49$ & $<0.001$ & $87(87.9 \%)$ \\
\hline GGT $(\mathrm{U} / \mathrm{L})$ & $746.15 \pm 563.77$ & $376.84 \pm 286.75$ & $<0.001$ & $94(94.9 \%)$ \\
\hline ALP $(\mathrm{U} / \mathrm{L})$ & $630.19 \pm 422.61$ & $373.66 \pm 299.1$ & $<0.001$ & $94(94.9 \%)$ \\
\hline AST $(\mathrm{U} / \mathrm{L})$ & $197.95 \pm 127.62$ & $107.4 \pm 109.13$ & $<0.001$ & $90(90.9 \%)$ \\
\hline ALT $(\mathrm{U} / \mathrm{L})$ & $196.99 \pm 184.8$ & $101.52 \pm 162.27$ & $<0.001$ & $87(87.9 \%)$ \\
\hline
\end{tabular}

Table 3. Additional interval procedures.

\begin{tabular}{|l|c|}
\hline Procedure & n (\%) \\
\hline $\begin{array}{l}\text { Percutaneous transhepatic biliary } \\
\text { stenting }\end{array}$ & $62(88.6 \%)$ \\
\hline Endoscopic stenting & $4(5.7 \%)$ \\
\hline Operation & $3(4.3 \%)$ \\
\hline Percutaneous cholecystostomy & $1(1.4 \%)$ \\
\hline
\end{tabular}

Table 4. Drainage related complications.

\begin{tabular}{|l|l|}
\hline Complication & n (\%) \\
\hline Catheter dislocation & $26(76.5 \%)$ \\
\hline Haemobilia & $3(8.8 \%)$ \\
\hline Bleeding from abdominal wall incision & $2(5.9 \%)$ \\
\hline Postprocedural cholangitis & $2(5.9 \%)$ \\
\hline Biliary peritonitis & $1(2.9 \%)$ \\
\hline
\end{tabular}


proximal/hilar cholangiocarcinoma was diagnosed and the remaining twenty nine (29.3\%) patients had biliary obstruction due to metastatic liver disease (Table 1). Acute cholangitis was present in fifty two cases (52.5\%). Prior to percutaneous procedure in fifty eight patients $(58.6 \%)$ unsuccessful ERCP was attempted. Two of these patients have developed acute post ERCP cholangitis. Ninety nine patients received 124 successful PTBD procedures (averaging 1.25 procedures per patient). Twenty three patients received 1 additional percutaneous procedure, and one patient - 2 additional percutaneous drainage procedures after initial percutaneous drain dislocation. Eighty eight patients had successful PTBD at first attempt (success rate 88.9\%). In eleven patients PTBD was performed during the same admission by following attempts.

At the time of discharge or prior to removal of biliary drainage catheter level of total serum bilirubin, gammaglutamyltransferase (GGT), alkaline phosphatase (ALP), aspartate transaminase (AST) and alanine transaminase (ALT) reduced significantly, compared to values prior to PTBD (Table 2). Following PTBD 70 patients $(70.7 \%)$ underwent additional interval procedures. In 62 (88.6\%) of these a successful percutaneous transhepatic biliary stenting was performed with three patients receiving simultaneous biliary stenting and drainage procedures. One patient with obstructive jaundice caused by pancreatic tumor, poor general condition, acute renal insufficiency, and pneumonia, had intrahepatic drainage catheter dislocation, followed by percutaneous cholecystostomy. In two patients Whipple procedure was performed and one patient underwent right hepatectomy with hepaticojejunostomy. All remaining patients with successful PTBD were directed to oncology department for further systemic treatment (Table 3). Average in hospital stay was $25.5 \pm 17.9$ days, ranging from 6 to 124 days. In hospital stay after PTBD was $19.9 \pm 17.3$ days, ranging from 2 to 116 days. Drainage related complications occurred in thirty four (34.3\%) patients with drain dislocation being the most common $(\mathrm{n}=26(76.5 \%)$. In case of drain dislocation, additional PTBD procedures were carried out, if possible. Three patients with haemobilia $(8.8 \%)$ were successfully treated by transcatheter embolization. Two patients with external bleeding at the location of drain insertion (5.9\%) were managed conservatively. All complications associated with bleeding were diagnosed and managed immediately after drainage procedure. Postprocedural cholangitis developed in two (5.9\%) patients and was treated conservatively (antibacterial therapy). Single patient with biliary peritonitis, caused by drain dislocation, was treated by ultrasound guided percutaneous abdominal drainage and antibacterial therapy (Table 4). Overall hospital mortality reached $27.3 \%$ (27 patients) with 1 drainage related death (procedure related mortality rate $-3.7 \%$ ). Deceased patient was 86 years old female with acute cholangitis and jaundice due to the hilar cholangiocarcinoma. The patient developed biliary peritonitis and sepsis caused by catheter dislocation 14 days after PTBD. All other in hospital deaths were due to advanced stage of disease and severe comorbidities, which were present in $19(70.4 \%)$ out of 27 patients. Fourteen $(51.9 \%)$ deceased patients had persistent acute cholangitis, which was one of the factors, leading to fatal outcome.

\section{Discussion}

Our retrospective study revealed that PTBD was an important and effective alternative to other biliary drainage methods in our facility. Our results do not differ significantly when compared to other similar studies $[1,5,6]$.

Biliary obstruction occurs, when bile passage from bile ducts to intestines is blocked [6]. Main causes of biliary obstruction are divided into malignant and benign, with gallstones, biliary tract strictures and chronic pancreatitis reported as the most common benign diseases. Metastases, pancreatic cancer and cholangiocarcinoma are the most common malignant causes of biliary obstruction [6]. Pancreatic ductal adenocarcinoma was the main cause of malignant obstruction in our cohort, sharing similar results with others [5,7]. Hilar cholangiocarcinoma and liver metastases from colorectal malignancies were second and third leading causes of obstruction. At the time of diagnosis, majority of malignancies are at advanced stage and incurable, making palliative treatment the only option [5]. For patients with malignant biliary obstruction ERCP is the first choice procedure to decompress the biliary tract $[8,9]$. In some cases, such as duodenal obstruction or altered anatomy due to previous surgery, ERCP may fail, making PTBD an important alternative, with a satisfactory therapeutic success rate $[10,11]$. PTBD has been shown to be effective to achieve biliary decompression and allow patients receive further treatment [12].

In recent years, mainly because of PTBD associated complications, alternative methods have been developed [6]. One of the most frequently used alternatives to PTBD is Endoscopic Ultrasound (EUS) guided biliary drainage (EUSBD). Recent studies revealed that EUS-BD and PTBD share similar technical and clinical success rates, with PTBD being slightly more successful technically [7]. However, differences in the rate of adverse effects is reported. Results of newly published study by Avila et al. [13] shows, that EUS-BD is associated with not only lower complication rates, but shorter hospital stay and lower cost. To sum up, EUS-BD offers safe and effective alternative to PTBD, without use of external drainage catheter. Lack of evidence from multicenter and randomized controlled trials analyzing safety and therapeutic 
profiles of EUS-BD, still limits its use as a standard procedure. Meanwhile PTBD with its widespread availability remains primary alternative to unsuccessful ERCP [14].

The main objective of our study was to analyze the clinical outcomes of ultrasound guided PTBD and its role in further palliative treatment of malignant biliary diseases. Clinical success is described as a certain amount of reduction in serum bilirubin values after the PTBD, as compared to these values prior to drainage procedure $[5,15]$. Similarly, we have shown significantly reduced bilirubin and liver enzyme values after PTBD, indicating satisfactory clinical effectiveness.

Reported rate of procedure related complications ranges from $7.8 \%$ to $39.2 \%$. Rate of drainage related deaths ranges from $0.7 \%$ to $2.98 \%[4-7,14]$. Our result of $34.3 \%$ drainage related adverse effects (with 1 drainage related death) does not exceed the reported morbidity and mortality rates. Use of ultrasound guided drainage, higher patient age, high incidence of comorbidities (59.6\%), and no use of prophylactic antibiotics prior to PTBD procedure may be just a few reasons accounting for relatively high postprocedural morbidity in our facility. One of the important and easily corrected variables to improve safety of PTBD might be preoperative antibiotic prophylaxis. Heedman et al. [16] described significantly lower drainage related complication rates after antibiotic prophylaxis for patients with malignant biliary obstruction. Liu et al. [17] reported better drainage effectiveness in patients, who received PTBD via left liver lobe entry. Left liver lobe entry for PTBD drain insertion was routinely used at our institution.. However, in eight patients right or bilobar approach was chosen. No differences in success and morbidity rates were observed.

Avoiding complications and discomfort, related to external drainage catheter, percutaneous transhepatic biliary stenting (PTBS) is used as a safe and effective palliative treatment of choice for inoperable hepatobiliary tract malignancies [18]. Bare self expandable metallic stents (SEMS) are used because of their superiority to percutaneous plastic stents $[19,20]$. PTBD was used as a first step, followed by percutaneous stenting at our institution. During two year period $62.6 \%$ patients have been successfully stented during the same hospital admission. Our results are promising when compared to the data published by Robson et al. [1], where only $41 \%$ of patients received biliary stent insertion after external drainage procedure for malignant biliary obstruction.

\section{Conclusions}

Percutaneous transhepatic biliary drainage acts as a relatively safe and effective method to reduce malignant obstructive jaundice. Despite satisfactory results of PTBD further adjustments are needed to minimize procedure related morbidity rates.

Conflict of interest statement: the authors declare no conflicts of interest.

\section{References}

1. Robson PC, Heffernan N, Gonen M, Thornton R, Brody LA, Holmes R. et al. Prospective study of outcomes after percutaneous biliary drainage for malignant biliary obstruction. Ann Surg Oncol 2010;17(9):2303-11. https://doi.org/10.1245/s10434-010-1045-9

2. Tsetis D, Krokidis M, Negru D, Prassopoulos P. Malignant biliary obstruction: the current role of interventional radiology. Ann Gastroenterol Ann Gastroenterol [Internet]. 2016;29(291):336. Available from: www.annalsgastro.gr

3. Crosara Teixeira M, Mak MP, Marques DF, Capareli F, Carnevale FC, Moreira AM. et al. Percutaneous transhepatic biliary drainage in patients with advanced solid malignancies: Prognostic factors and clinical outcomes. J Gastrointest Cancer 2013;44(4):398-403.

https://doi.org/10.1007/s12029-013-9509-3

4. Ahn S, Lee YS, Lim KS, Lee JL. Malignant biliary obstructions: can we predict immediate postprocedural cholangitis after percutaneous biliary drainage? Support Care Cancer 2013;21(8):2321-6.

5. Zhang GY, Li WT, Peng WJ, Li GD, He XH, Xu LC. Clinical outcomes and prediction of survival following percutaneous biliary drainage for malignant obstructive jaundice. Oncol Lett 2014;7(4):1185-90.

https://doi.org/10.3892/ol.2014.1860

6. Nennstiel S, Weber A, Frick G, Haller B, Meining A, Schmid RM. et al. Drainage related complications in percutaneous transhepatic biliary drainage: an analysis over 10 years. J Clin Gastroenterol [Internet] 2014;49(9):764-70. Available from: http://www.ncbi.nlm.nih.gov/pubmed/25518004

7. Khashab MA, Valeshabad AK, Afghani E, Singh VK, Kumbhari $\mathrm{V}$, Messallam A. et al. A comparative evaluation of eus-guided biliary drainage and percutaneous drainage in patients with distal malignant biliary obstruction and failed ERCP. Dig Dis Sci 2015;60(2):557-65.

https://doi.org/10.1007/s10620-014-3300-6

8. Consensus NIH, Statements S. NIH State-of-the-Science Statement on Endoscopic Retrograde Cholangiopancreatography (ERCP ) Office of the Director 2002;19(1).

9. The Role of ERCP in diseases of the biliary tract and pancreas: guidelines for clinical application. Gastrointest Endosc [Internet] 1999;50(6):915-20. Available from: http://www. sciencedirect.com/science/article/pii/S0016510799701951

10. Enochsson L, Swahn F, Arnelo U, Nilsson M, Löhr M, Persson G. Nationwide, population based data from 11,074 ERCP procedures from the Swedish Registry for Gallstone Surgery and ERCP. Gastrointest Endosc [Internet] 2010 
Dec 1 [cited 2018 Apr 24];72(6):1175-1184.e3. Available from: https://www.sciencedirect.com/science/article/pii/ S0016510710019565?via\%3Dihub

11. Leng J-J, Zhang N, Dong J-H. Percutaneous transhepatic and endoscopic biliary drainage for malignant biliary tract obstruction: a metaanalysis. World J Surg Oncol [Internet]. 2014;12(1):272. Available from: http://www.ncbi.nlm.nih.gov/ pubmed/25148939

12. Tuqan W, Innabi A, Alawneh A, Farsakh FA, Al-Khatib M. Prediction of survival following percutaneous biliary drainage for malignant biliary obstruction. J Transl Intern Med [Internet] 2017 Jun 30;5(2):127-31. Available from: http://www.ncbi. nlm.nih.gov/pmc/articles/PMC5506413/

13. Téllez-Avila FI, Herrera-Mora D. et al. Biliary drainage in patients with failed ercp: percutaneous versus EUS guided drainage. Surg Laparosc Endosc Percutan Tech 2018;28(3):183-7 https://doi.org/10.1097/SLE.0000000000000528

14. Artifon ELA, Aparicio D, Paione JB, Lo SK, Bordini A, Rabello $C$. et al. Biliary drainage in patients with unresectable, malignant obstruction where ERCP fails: Endoscopic ultrasonography guided choledochoduodenostomy versus percutaneous drainage. J Clin Gastroenterol 2012;46(9):768-74.

https://doi.org/10.1097/MCG.0b013e31825f264c

15. Wenchang YU, Kongzhi Z, Shiguang C. et al. Percutaneous transhepatic biliary drainage for obstructive jaundice caused by metastatic gastric cancer: Efficacy and complications. Chinese-German J Clin Oncol [Internet] 2011;10(3):157-61. https://doi.org/10.1007/s10330-011-0752-4

16. Heedman PA, Åstradsson E, Blomquist K, Sjödahl R. Palliation of malignant biliary obstruction: adverse events are common after percutaneous transhepatic biliary drainage. Scand J Surg [Internet] 2017 Sep 25;107(1):48-53. Available from: https:// doi.org/10.1177/1457496917731192

https://doi.org/10.1177/1457496917731192

17. Liu Y-S, Lin C-Y, Chuang M-T, Tsai Y-S, Wang C-K, Ou $\mathrm{M}-\mathrm{C}$. Success and complications of percutaneous transhepatic biliary drainage are influenced by liver entry segment and level of catheter placement. Abdom Radiol [Internet] 2018 Mar;43(3):713-2.

https://doi.org/10.1007/s00261-017-1258-5

18. Dambrauskas Ž, Paškauskas S, Lizdenis P, Uktveris R, Pranculis A, Kaupas RS. et al. Percutaneous transhepatic biliary stenting: The first experience and results of the Hospital of Kaunas University of Medicine. Medicina (B Aires) 2008;44(12):969-76. https://doi.org/10.3390/medicina44120121

19. Moss AC, Morris E, MacMathuna P. Palliative biliary stents for obstructing pancreatic carcinoma. Cochrane Database Syst Rev [Internet] 2006;(2). Available from: http://dx.doi. org/10.1002/14651858.CD004200.pub4

https://doi.org/10.1002/14651858.CD004200.pub4

20. Tsuyoshi M, Ichiro Y, Masanori N, Shinpei D, Takuji I, Keisuke I. et al. Metallic stents are more efficacious than plastic stents in unresectable malignant hilar biliary strictures: a randomized controlled trial. J Hepatobiliary Pancreat Sci [Internet] 2012 Mar 14;20(2):214-22.

https://doi.org/10.1007/s00534-012-0508-8

\section{PERKUTANINIS TULŽIES LATAKŲ DRENAVIMAS DĖL PIKTYBINĖS BILIARINĖS OBSTRUKCIJOS R.Riauka, P.Ignatavičius, G.Barauskas}

Raktažodžiai: biliarinè obstrukcija, perkutaninis, tulžies latakų, drenavimas.

Santrauka

Ivadas. Perkutaninis tulžies latakų drenavimas (PTLD) - saugus ir efektyvus metodas pasiekti biliarinę dekompresiją pacientams, kuriems mažiau invazyvūs drenavimo metodai negalimi. Šio darbo tikslas - įvertinti PTLD rezultatus Lietuvos sveikatos mokslų universiteto ligoninès Kauno klinikų (LSMUL KK) Chirurgijos klinikos pacientams, kuriems diagnozuota piktybine biliarine obstrukcija.

Metodika. Retrospektyvinè analizė pacientų, kuriems 2014 2015 metais LSMUL KK Chirurgijos klinikoje atliktas perkutaninis tulžies latakų drenavimas dèl piktybinès biliarinès obstrukcijos. Vertinta pacientų demografiniai duomenys, laboratorinių rodiklių kitimas, komplikacijos, baigtys, hospitalizavimo trukmè ir mirštamumas.

Rezultatai. Dvejų metų laikotarpiu 99 pacientams (amžiaus mediana - 68 metai, (44 - 95) buvo atliktos 124 perkutaninio drenavimo procedūros dèl piktybinès biliarinès obstrukcijos. Prieš perkutaninį drenavimą 58 pacientams $(58,6 \%)$ buvo nesèkmingai bandoma atlikti ERCP procedūrą. 40 pacientų $(40,4 \%)$ mechaninè gelta buvo sukelta periampulinių navikų, 30 (30,3\%) - kepenų vartų cholangiokarcinomos, 29 (29,3\%) kepenų metastazių. Ūmų cholangitą prieš drenavimą turejjo $52(52,5 \%)$ pacientai. Bendro bilirubino reikšmès po perkutaninio drenavimo procedūros sumažèjo 87 pacientams $(87,9 \%)$ ir buvo statistiškai reikšmingai mažesnès, lyginant su reikšmèmis prieš drenavimą (nuo 293,72 $\pm 131,9 \mu \mathrm{mol}$ iki 193,11 $\pm 117,49 \mu \mathrm{mol}, \mathrm{p}<0,05)$. Gama glutamyltransferazės ir šarminès fosfatazès reikšmès po drenavimo sumažejo atitinkamai 94 pacientams $(94,9 \%)$. 70 pacientu $(70,7 \%)$ po drenavimo buvo atliktos papildomos gydomosios procedūros. Dažniausiai, 62 pacientams $(88,6 \%)$, atliktas perkutaninis transhepatinis stentavi-

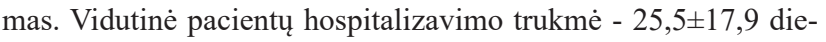

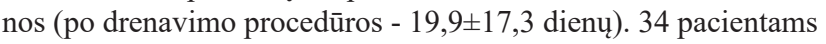
$(34,3 \%)$ pasireiškè su drenavimo procedūra susijusios komplikacijos. Dažniausiai pasireiškusi komplikacija - dreno dislokacija 26 pacientams (76,5\%). Hospitalizavimo metu mirè 27 pacientai $(27,3 \%)$. Su procedūra susijusio mirštamumo dažnis $-3,7 \%(n=1)$.

Išvados. Perkutaninis tulžies latakų drenavimas yra saugi ir efektyvi procedūra pasiekti biliarinès sistemos dekompresiją, kai mažiau invazyvūs drenavimo metodai negalimi ir yra pirmasis žingsnis toliau gydant pacientus su piktybine biliarine obstrukcija.

Adresas susirašinèti: romualdasriauka@gmail.com

Gauta 2018-10-11 